\title{
THE DEATH OF THE LATE MR. E. T. BUSK AND THE POSTHUMOUS AWARD TO HIM OF THE GOLD MEDAL OF THE AERONAUTICAL SOCIETY.
}

In announcing, in the issue of July, 19r4, the award of the Gold Medal of the Aëronautical Society of Great Britain to Prof. Bryan, it was remarked that his work had fortunately been appreciated in the quarters where time and money were available to turn it to practical use. Those who had followed the lecture by Mr. Bairstow (see the April Journal, 1914, p. 84) and Dr. Glazebrook's Wilbur Wright Lecture (see the July Journal, I9I4, p. 294) were in a position to know that the quarters referred to were the Royal Aircraft Factory and the National Physical Laboratory, but only a few were in a position to know how much importance was to be attached to the work of the Mr. Busk mentioned by Mr. Bairstow and Dr. Glazebrook. When, at the Wilbur Wright Memorial Banquet, I9I4, Colonel Seely had made the first public announcement of his flight on the stable aeroplane produced at the Royal Aircraft Factory, the pilot's name had been veiled in anonymity, and only a privileged few knew that he was in fact the designer of the R.E.I. Those who knew, however, felt quietly confident of future stability work in this country, with such collaborators as $\mathrm{Mr}$. Busk and Mr. Bairstow at the beginning of their careers, and the shock of the former's tragic death was all the greater, therefore, when it became known that he had been burnt to death in the air on November 5 th, rgr 4. Instead of being able to look forward to the further triumphs that would undoubtedly have been his, we can now only place on record our great appreciation of what our late distinguished member had already accomplished and our very deep regret at his loss.

It is not permissible at the present juncture to discuss his career and work except in the general terms employed in the following obituary notice, kindly supplied by Mr. Mervyn O'Gorman, C.B. (Superintendent of the Royal Aircraft Factory):-

Edward Teshmaker Busk, born March 8th, 1886, died November 5th, 19r4, was educated at Harrow and Cambridge. A Scholar of King's College, Cambridge, he secured First Class Honours in the Mechanical Sciences Tripos, obtained the John Wimbourne Prize, etc. He distinguished himself early as an engineer during the years he worked at Messrs. Halls and Co., of Dartford.

He joined the staff of the Royal Aircraft Factory as Assistant Engineer in Charge of Physical Experimental work on June Ioth, I9I2. There he devoted much of his time to the mathematics and dynamics of stable flight on the full size, as distinct from the model, aeroplane. He introduced many valuable improvements, of which it is not permissible to give particulars at the present juncture, his work not being confined to the solution of aeroplane stability, but covering a wide and varied range. His valuable researches into the nature and cause of wind gusts and his work in connection with the offensive and defensive uses of aircraft in warfare may be specially mentioned. He also guided his branch in the production of aeroplane instruments, some of which were exhibited at the Royal Society in May and June, I9r3, by permission of the Superintendent, Royal Aircraft Factory.*

* Members present at Mr. O'Gorman's lecture to the Aëronautical Society on January 27th, igr 3 (Aeronautical Journal, April, I9I3, pp. 59-82), will remember Mr. Busk's introduction as the designer of the "ripometer," then first publicly exhibited, and his contributions to our discussions were always interesting and valuable. $-\left[\mathrm{ED}_{\mathrm{D}}\right]$ 
By the autumn of 1913 he had carried his researches so far that complete stability without material loss of efficiency could be obtained for any aeroplane designed in accordance with his results. In November, 1913, he was able to make flights of several hours' duration in winds up to $3^{8}$ miles per hour, without at any time using any balancing, controlling, or steering mechanism whatever, save for alighting purposes. He took Colonel Seely on such an uncontrolled flight, and later on made demonstration flights before their Majesties the King and Queen. The matter was introduced in practical form to the Royal Flying Corps by his taking the Commanding Officer, Colonel Sykes, as passenger, from the Royal Aircraft Factory, Farnborough, to Salisbury Plain and back, while both passenger and flyer, being freed from the use of controls, wrote notes and observations continuously throughout the journey. This trial was repeated by Colonel Brancker as pilot as well as many other officers.

He was flying his own stable aeroplane at the time of its destruction by fire in the air, at Aldershot, at a height of some 800 feet.

So far as it has been possible to reconstruct the accident, the fire is ascribed to a spark igniting the petrol vapour, but the exact cause cannot well be traced owing to the complete destruction of the machine.

Mr. Busk's scientific attainments and versatility were shown by the variety of matters entrusted to him by the Superintendent of the Royal Aircraft Factory. These included the general control of the chemical, metallurgical and physical research and test work at the Factory.

His loss is deeply deplored at Farnborough, as much because of his cheery and charming personality as because of the gallant manner in which he faced every kind of risk in the verification of the mathematical theories he had himself worked out or inspired.

He resembled other men of genius in the simplicity of his methods and the speed at which he worked, and he was remarkable for the soundness of the scientific judgments he arrived at. His youth, for he was only 28 years of age, is an added cause for regretting the termination of a career so brilliantly commenced.

He was buried, with military honours, in the Military Cemetery, Aldershot, on Monday, 9th November, I9I4. The Society sent a wreath and was officially represented by the Secretary. Amongst the large number of naval and military officers and men who were present was a detachment of the London Electrical Engineers, of which body Mr. Busk was a Second Lieutenant.

At a meeting of the Council of the Society, held on the I8th November last, it was unanimously decided to award to Mr. Busk the Gold Medal of the Aerronautical Society of Great Britain, in recognition of his distinguished services to Aeronautical Science. The medal will be presented to Mrs. Busk on her son's behalf at a date to be subsequently fixed.

On the death of Mr. Busk a movement was immediately initiated at the Royal Aircraft Factory to found a Memorial. From this two schemes have arisen, due respectively to $\mathrm{Mr}$. Mervyn O'Gorman, C.B., and to Sir Edward Busk, as representing Mrs. Busk and other members of the family. The former scheme provides for an Edward Busk Lecture, the latter for an Edward Busk Studentship. Full details will be announced later. 